\title{
Studies on the Effect of Phosphorus Levels on Yield Attributes and Yield of Groundnut in South Odisha Condition
}

\author{
Dokkara Prem Kumar ${ }^{* 1}$, Tanuj Kumar Mandal ${ }^{1}$, A. Zaman ${ }^{1}$ and Arunabha Pal ${ }^{2}$
}

${ }^{1}$ Department of Agronomy, M.S. Swaminathan School of Agriculture, Centurion University of Technology and Management, Paralakhemundi-761 211, India

${ }^{4}$ Department of Soil Science, M.S. Swaminathan School of Agriculture, Centurion University of Technology and Management, Paralakhemundi-761 211, India

*Corresponding author: dokkarapremkumar@gmail.com (ORCID ID: 0000-0002-2042-0366)

Paper No. 802

Received: 07-07-2019

Revised: 15-10-2019

Accepted: 26-11-2019

\begin{abstract}
Proper basal application of phosphorus has a tremendous influence on the kernel yield, pod yield and other yield contributing characteristics. In view of this, an experiment was conducted during summer season (February to June) of 2018 at Bagusala Farm (2339' N latitude, 87²4' E longitude) of M.S. Swaminathan School of Agriculture, Centurion University of Technology and Management, Paralakhemundi, Odisha to find out the effect of various phosphorus levels on yield attributes and yield of groundnut. Seven levels of basal application of phosphorus rates, namely, 0 (control), 20, 40, 60, 80, 100, and $120 \mathrm{~kg} \mathrm{P} \mathrm{ha}^{-1}$ were tested in randomized complete block design (RCBD) design with four replications. The experiment revealed that the basal application of $\mathrm{P}_{2} \mathrm{O}_{5}$ at the rate of $100 \mathrm{~kg} \mathrm{ha}^{-1}$ registered superior performance in expression of yield attributes like number of pods per plant, number of kernels per plant, kernel weight per plant and yield of groundnut. It may be concluded that to obtain higher productivity of groundnut during summer season in sandy loam soils of south Odisha, basal application of $\mathrm{P}_{2} \mathrm{O}_{5} @ 100 \mathrm{~kg}^{-1}$ ha recommended.
\end{abstract}

\section{Highlights}

( Basal application of phosphate $\left(\mathrm{P}_{2} \mathrm{O}_{5}\right) @ 100 \mathrm{~kg} \mathrm{ha}^{-1}$ emerged as the best option for obtaining sustainable yield under South Odisha agroecology.

Keywords: Groundnut, phosphorus, basal application, yield

Groundnut (Arachis hypogaea $\mathrm{L}$ ) is an annual legume native to South America, and it is presently grown worldwide mostly in tropical, sub-tropical and warm temperate regions. In India, it is grown in 11 states in an area of 4.6 million ha with a production of 6.73 million tonnes of pods per annum. The average productivity of groundnut in India is about $1465 \mathrm{~kg} \mathrm{ha}^{-1}$ as against the world's average yield of $1590.1 \mathrm{~kg} \mathrm{ha}^{-1}$ (GoI, 2017). However, in Odisha the productivity of groundnut is 1098 $\mathrm{kg} \mathrm{ha}^{-1}$ which is lower than the national average. The groundnut productivity in Odisha is low due to some production constraints like poor and imbalanced nutrition of crop, growing groundnut on marginal lands and improper agronomic management. Among different agronomic practices, nutrient management is one which accelerates growth and productivity of the crop. Therefore, it is essential to have more focus to the nutrition of the groundnut to enhance its productivity. Groundnut is called a self fertilizing crop, nevertheless, it is very exhaustive crop compared to other legumes because a very little portion of the plant residue is left in the soil after harvest (Varade and Urkude 1982). Faulty nutrient management has been identified as one of the important constraints in groundnut production. Among different fertilizers, phosphorus is having some distinct role for the proper functioning of the 
nodules and root growth in legumes. Generally, a oilseed crop has greater requirement for phosphorus (Pasricha and Aulakh 1986). Besides, phosphorus is essential for the formation of chlorophyll and protoplasm, cell division and development of meristematic tissues, also helps in the seed development and maturity of plant (Black 1965). Thus, it is imperative to application of sufficient phosphorus for maximum yield of groundnut. Earlier researchers noted significant impact of applied P fertilizers on growth characters, yield attributes and yield of groundnut (Barik et al. 1994; Sharma and Yadav 1997; Rao and Shaktawat 2001; Shivakumar et al. 2014). There is insufficiency in research activities on phosphorus requirement of groundnut and the present study has been carried out to evaluate the requirement of phosphatic fertilizer under south Odisha conditions.

\section{MATERIALS AND METHODS}

The field experiment was carried out during the summer of 2018 (Feb- May) at Bagusala Farm, M.S. Swaminathan School of Agriculture, Centurion University of Technology and Management, Paralakhemundi, Odisha on sandy loam soil, having a pH-6.5 with $226 \mathrm{~kg}$ ha-1 of available nitrogen, 324 $\mathrm{kg} \mathrm{ha}{ }^{-1}$ of available phosphorous, $591 \mathrm{~kg} \mathrm{ha}^{-1}$ of available potassium and medium in organic carbon $0.50 \%$. The experimental field was a medium land with good irrigation and drainage facilities. The soil was a typical new alluvial, inceptisol having moderate water holding capacity. The experiment was conducted in randomized completely block design. The experiment has 7 levels of phosphorus, namely, $\mathrm{P}_{0}-$ control $\left(\mathrm{No} \mathrm{P}_{2} \mathrm{O}_{5}\right), \mathrm{P}_{1}-$ Basal application of $\mathrm{P}_{2} \mathrm{O}_{5} @ 20 \mathrm{~kg} \mathrm{ha}^{-1}, \mathrm{P}_{2}-$ Basal application of $\mathrm{P}_{2} \mathrm{O}_{5}$ @ $40 \mathrm{~kg} \mathrm{ha}{ }^{-1}, \mathrm{P}_{3}-$ Basal application of $\mathrm{P}_{2} \mathrm{O}_{5} @ 60 \mathrm{~kg}$ ha-1 $\mathrm{P}_{4}$ - Basal application of $\mathrm{P}_{2} \mathrm{O}_{5} @ 80 \mathrm{~kg} \mathrm{ha}^{-1}, \mathrm{P}_{5}$ - Basal application of $\mathrm{P}_{2} \mathrm{O}_{5} @ 100 \mathrm{~kg} \mathrm{ha}^{-1}, \mathrm{P}_{6}$ - Basal application of $\mathrm{P}_{2} \mathrm{O}_{5} @ 120 \mathrm{~kg} \mathrm{ha}^{-1}$. The K-6 variety of groundnut seeds were sown on 2nd February 2018 at a spacing of $30 \mathrm{~cm} \times 10 \mathrm{~cm}$. A common dose of $20 \mathrm{~kg} \mathrm{~N}$, varied $\mathrm{P}$ rates as per the treatments and common dose of $40 \mathrm{~kg} \mathrm{~K}_{2} \mathrm{O} \mathrm{ha}^{-1}$ in all treatments were applied as basal dose through urea, single super phosphate and muriate of potash fertilizers respectively. Five irrigations were given during entire crop growth period. Rainfall received during the crop growth period was $12.73 \mathrm{~cm}$. Observations on yield attributes and yield were recorded and briefly discussed in the following paragraphs.

\section{RESULTS AND DISCUSSION}

\section{Yield Parameters}

Levels of phosphorus significantly influenced the yield attributing characters of groundnut. The highest number of pods plant ${ }^{-1}$ (15.55) was recorded with $\mathrm{P}_{5}$ (basal application of $\mathrm{P}_{2} \mathrm{O}_{5} @ 100 \mathrm{~kg} \mathrm{ha}^{-1}$ ) and it differed significantly with all other treatments. Application of phosphorus had no significant effect on the number of kernels per pod ${ }^{-1}$. Maximum number of kernels pod $^{-1}(1.50)$ was recorded by $\mathrm{P}_{5}$ (basal application of $\mathrm{P}_{2} \mathrm{O}_{5} @ 100 \mathrm{~kg} \mathrm{ha}^{-1}$ ), whereas the lowest number of kernels pod ${ }^{-1}(1.30)$ was recorded by $\mathrm{P}_{2}$ (basal application of $\mathrm{P}_{2} \mathrm{O}_{5} @ 40 \mathrm{~kg} \mathrm{ha}^{-1}$ ). The number of kernels plant ${ }^{-1}$ was affected significantly by the application of different levels of phosphorus. The highest number of kernels plant ${ }^{-1}(21.30)$ was recorded with $\mathrm{P}_{5}$ (basal application of $\mathrm{P}_{2} \mathrm{O}_{5} @ 100$ $\mathrm{kg} \mathrm{ha}^{-1}$ ) which was significantly superior to all other treatments except $\mathrm{P}_{6}$ (basal application of $\mathrm{P}_{2} \mathrm{O}_{5} @ 120$ $\left.\mathrm{kg} \mathrm{ha}^{-1}\right)$. The highest shelling percentage $(73.12 \%)$ was recorded under $\mathrm{P}_{1}$ (basal application of $\mathrm{P}_{2} \mathrm{O}_{5}$ @ $20 \mathrm{~kg} \mathrm{ha}^{-1}$ ) and the lowest shelling percentage (64.31\%) was recorded with $\mathrm{P}_{4}$ (basal application of $\left.\mathrm{P}_{2} \mathrm{O}_{5} @ 80 \mathrm{~kg} \mathrm{ha}^{-1}\right)$. The highest kernel weight plant ${ }^{-1}$ $\left(5.85 \mathrm{~g}\right.$ ) was recorded was recorded with $\mathrm{P}_{5}$ (basal application of $\left.\mathrm{P}_{2} \mathrm{O}_{5} @ 100 \mathrm{~kg} \mathrm{ha}^{-1}\right)$ and $\mathrm{P}_{0}\left(\mathrm{No}_{2} \mathrm{O}_{5}\right)$ recorded the lowest kernel weight plant ${ }^{-1}(4.45 \mathrm{~g})$ and $\mathrm{P}_{0}\left(\mathrm{No} \mathrm{P}_{2} \mathrm{O}_{5}\right)$ was found to be statistically at par with $\mathrm{P}_{1}$ (basal application of $\mathrm{P}_{2} \mathrm{O}_{5} @ 20 \mathrm{~kg} \mathrm{ha}^{-1}$ ). The application of different levels of phosphorus had no significant effect on the 100 kernel weight. Highest values of 100 kernel weight (36.76 g) was recorded by $\mathrm{P}_{5}$ (basal application of $\mathrm{P}_{2} \mathrm{O}_{5} @ 100 \mathrm{~kg} \mathrm{ha}^{-1}$ ) and the lowest 100 kernel weight (36.38 g) was recorded under $\mathrm{P}_{0}\left(\mathrm{No} \mathrm{P}_{2} \mathrm{O}_{5}\right)$. The highest kernel yield $(1370 \mathrm{~kg}$ ha-1) was recorded with $\mathrm{P}_{5}$ (basal application of $\mathrm{P}_{2} \mathrm{O}_{5}$ @ $\left.100 \mathrm{~kg} \mathrm{ha}^{-1}\right)$ followed by $\mathrm{P}_{6}\left(1315 \mathrm{~kg} \mathrm{ha}^{-1}\right)$ and it differed significantly with all other treatments. The lowest kernel yield (1017.5 $\mathrm{kg} \mathrm{ha}^{-1}$ ) was recorded with $\mathrm{P}_{0}\left(\mathrm{No} \mathrm{P}_{2} \mathrm{O}_{5}\right)$, which was $34.64 \%$ less than the best treatment $\mathrm{P}_{5}$ (basal application of $\mathrm{P}_{2} \mathrm{O}_{5} @ 100 \mathrm{~kg}$ ha-1).The basal application of $\mathrm{P}_{2} \mathrm{O}_{5} @ 120 \mathrm{~kg} \mathrm{ha}^{-1}$ i.e. $\mathrm{P}_{6}$ achieved maximum values of pod yield (2029.50 $\left.\mathrm{kg} \mathrm{ha}^{-1}\right)$. The oil content (\%) and oil yield ( $\mathrm{kg}$ ha ${ }^{1}$ ) of groundnut were influenced significantly by 


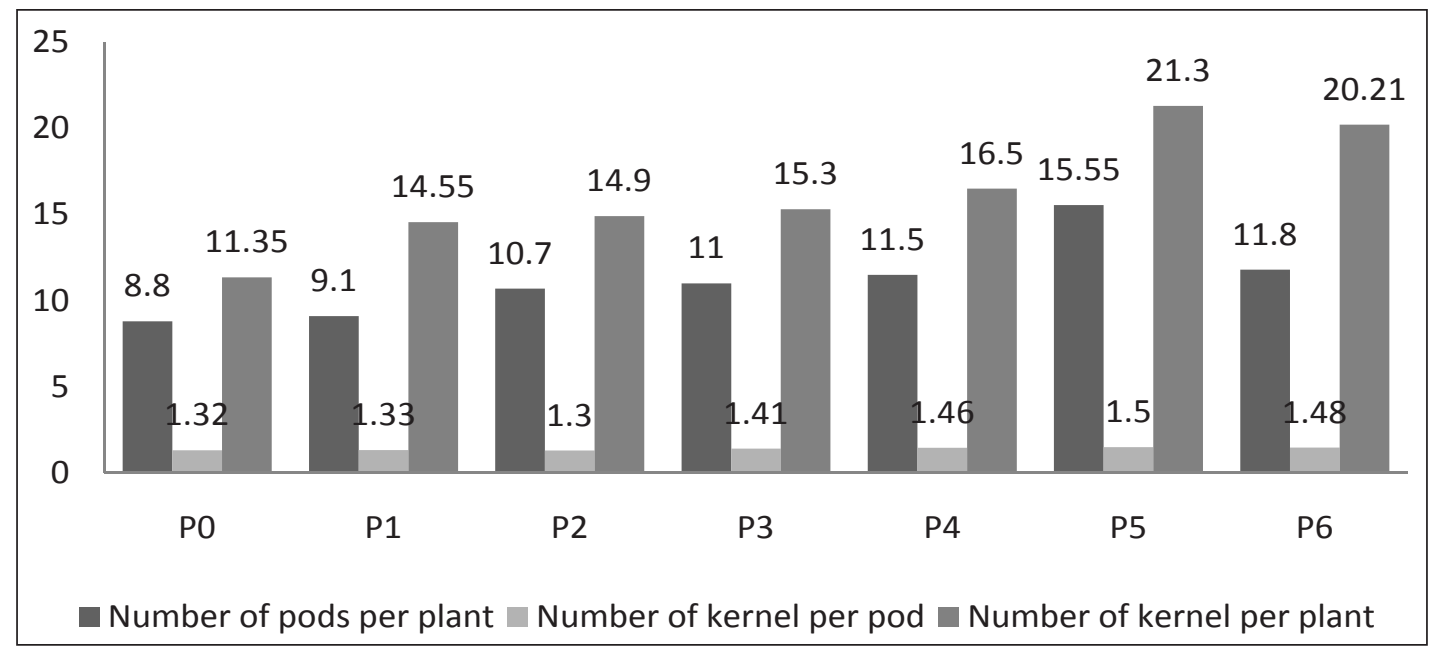

Fig. 1: Effect of phosphorus levels on number of pods per plant, number of kernel pod and number of kernel per plant

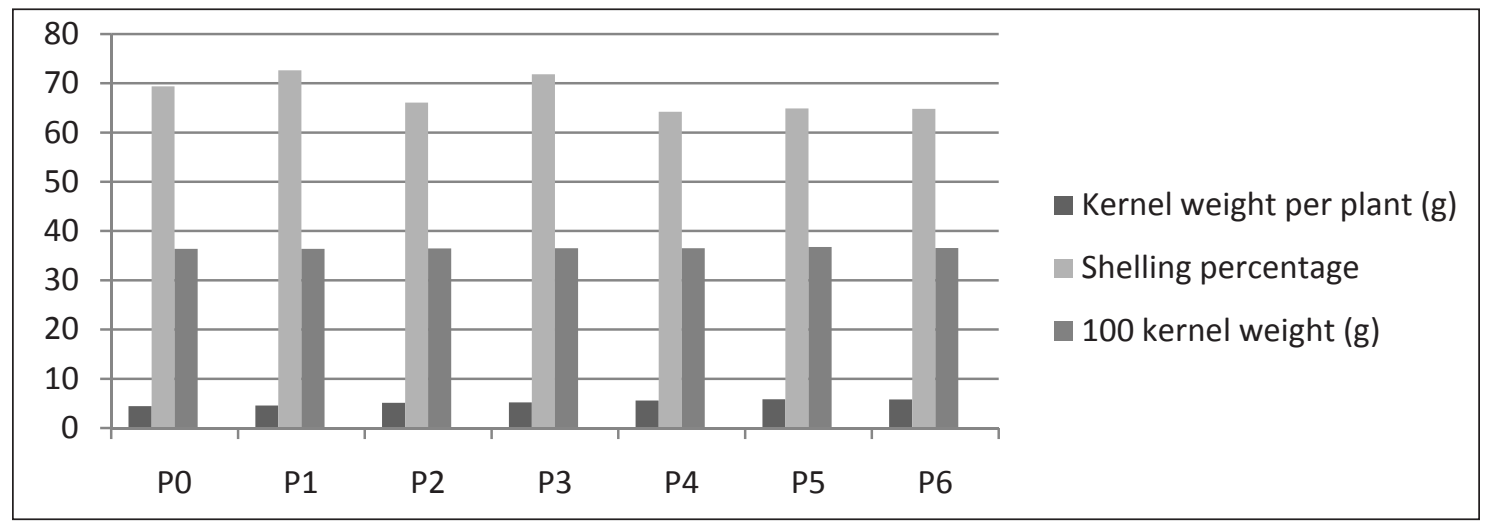

Fig. 2: Effect of phosphorus levels on kernel weight per plant, shelling percentage and 100 kernel weight

Table 1: Effect of phosphorus levels on the yield attributing characters of groundnut

\begin{tabular}{|c|c|c|c|c|c|c|}
\hline \multirow[b]{2}{*}{ Treatments } & \multicolumn{6}{|c|}{ Yield attributes } \\
\hline & $\begin{array}{l}\text { Number of } \\
\text { pods plant }^{-1}\end{array}$ & $\begin{array}{l}\text { Number of } \\
\text { kernel pod }^{-1}\end{array}$ & $\begin{array}{l}\text { Number of } \\
\text { kernel plant }^{-1}\end{array}$ & $\begin{array}{l}\text { Kernel weight } \\
\text { plant }^{-1}(\mathrm{~g})\end{array}$ & $\begin{array}{l}\text { Shelling } \\
\text { percentage }\end{array}$ & $\begin{array}{l}100 \text { kernel } \\
\text { weight }(\mathrm{g})\end{array}$ \\
\hline $\mathrm{P}_{0}-$ Control $\left(\mathrm{No}_{2} \mathrm{O}_{5}\right)$ & 8.80 & 1.32 & 11.35 & 4.45 & 69.92 & 36.38 \\
\hline $\begin{array}{l}\mathrm{P}_{1}-\text { basal application of } \\
\mathrm{P}_{2} \mathrm{O}_{5} @ 20 \mathrm{~kg} \mathrm{ha}^{-1}\end{array}$ & 9.10 & 1.33 & 14.55 & 4.55 & 73.12 & 36.40 \\
\hline $\begin{array}{l}\mathrm{P}_{2}-\text { basal application of } \\
\mathrm{P}_{2} \mathrm{O}_{5} @ 40 \mathrm{~kg} \mathrm{ha}^{-1}\end{array}$ & 10.70 & 1.30 & 14.90 & 5.10 & 66.25 & 36.47 \\
\hline $\begin{array}{l}\mathrm{P}_{3}-\text { basal application of } \\
\mathrm{P}_{2} \mathrm{O}_{5} @ 60 \mathrm{~kg} \mathrm{ha}^{-1}\end{array}$ & 11.00 & 1.41 & 15.30 & 5.20 & 72.43 & 36.50 \\
\hline $\begin{array}{l}\mathrm{P}_{4}-\text { basal application of } \\
\mathrm{P}_{2} \mathrm{O}_{5} @ 80 \mathrm{~kg} \mathrm{ha}^{-1}\end{array}$ & 11.50 & 1.46 & 16.50 & 5.60 & 64.31 & 36.52 \\
\hline $\begin{array}{l}\mathrm{P}_{5}-\text { basal application of } \\
\mathrm{P}_{2} \mathrm{O}_{5} @ 100 \mathrm{~kg} \mathrm{ha}^{1}\end{array}$ & 15.55 & 1.50 & 21.30 & 5.85 & 65.14 & 36.76 \\
\hline $\begin{array}{l}\mathrm{P}_{6}-\text { basal application of } \\
\mathrm{P}_{2} \mathrm{O}_{5} @ 120 \mathrm{kgha}^{1}\end{array}$ & 11.80 & 1.48 & 20.21 & 5.80 & 65.04 & 36.54 \\
\hline SEm \pm & 0.61 & 0.09 & 0.63 & 0.28 & 4.07 & 0.31 \\
\hline $\mathrm{CD}(\mathrm{P}=0.05)$ & 1.82 & NS & 1.87 & 0.85 & NS & NS \\
\hline CV (\%) & 10.95 & - & 7.75 & 10.97 & - & - \\
\hline
\end{tabular}




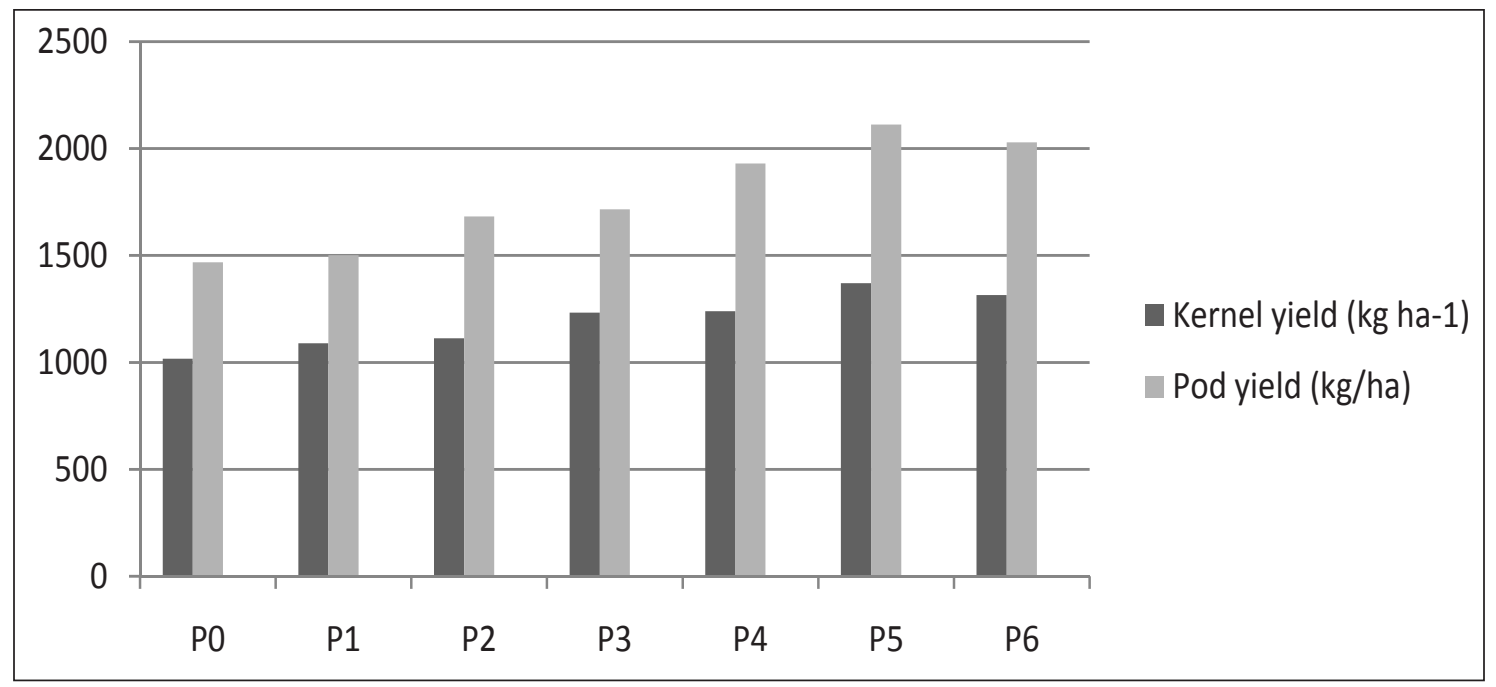

Fig. 3: Effect of phosphorus levels on the kernelyield $\left(\mathrm{kg} \mathrm{ha}^{-1}\right)$, pod yield $\left(\mathrm{kg} \mathrm{ha}^{-1}\right)$

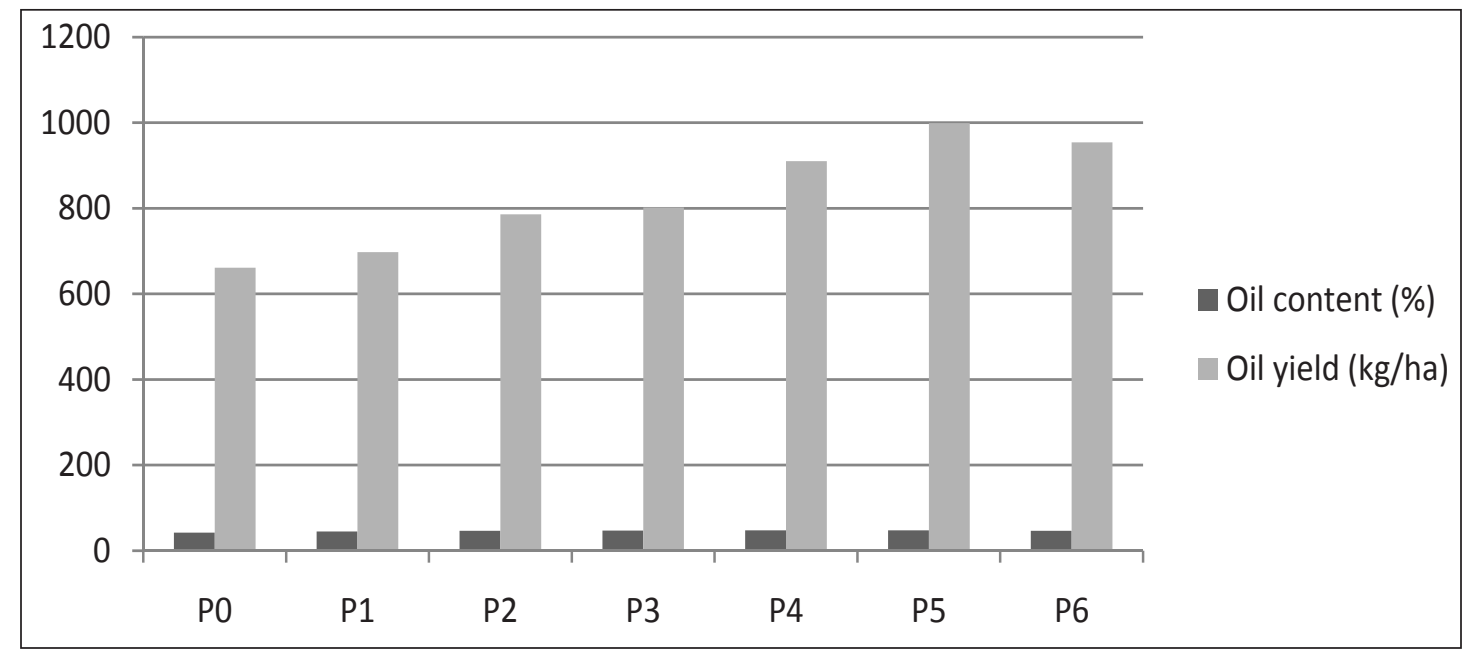

Fig. 4: Effect of phosphorus levels on the oil content (\%) and oil yield $\left(\mathrm{kg} \mathrm{ha}^{-1}\right)$ of groundnut

Table 2: Effect of phosphorus levels on the kernel yield $\left(\mathrm{kg} \mathrm{ha}^{-1}\right)$, pod yield $\left(\mathrm{kg} \mathrm{ha}^{-1}\right)$, oil content $(\%)$ and oil yield $\left(\mathrm{kg} \mathrm{ha}^{-1}\right)$ of groundnut

\begin{tabular}{|c|c|c|c|c|}
\hline Treatments & $\begin{array}{l}\begin{array}{l}\text { Pod yield } \\
\left(\mathrm{kg} \mathrm{ha}^{1}\right)\end{array} \\
\end{array}$ & $\begin{array}{l}\text { Kernel } \\
\text { yield }\left(\text { kgha }^{1}\right)\end{array}$ & $\begin{array}{l}\text { Oil content } \\
(\%)\end{array}$ & $\begin{array}{l}\text { Oil yield } \\
\left(\mathrm{kg} \mathrm{ha}^{-1}\right)\end{array}$ \\
\hline $\mathrm{P}_{0}-$ Control $\left(\mathrm{No}_{2} \mathrm{O}_{5}\right)$ & 1468.50 & 1017.50 & 42.55 & 661.16 \\
\hline $\mathrm{P}_{1}$ - basal application of $\mathrm{P}_{2} \mathrm{O}_{5} @ 20 \mathrm{~kg} \mathrm{ha}{ }^{1}$ & 1501.50 & 1090.00 & 44.75 & 697.89 \\
\hline $\mathrm{P}_{2}-$ basal application of $\mathrm{P}_{2} \mathrm{O}_{5} @ 40 \mathrm{~kg} \mathrm{ha}^{-1}$ & 1683.00 & 1112.50 & 46.70 & 786.12 \\
\hline $\mathrm{P}_{3}$ - basal application of $\mathrm{P}_{2} \mathrm{O}_{5} @ 60 \mathrm{~kg} \mathrm{ha}^{-1}$ & 1716.00 & 1232.50 & 47.25 & 802.26 \\
\hline $\mathrm{P}_{4}-$ basal application of $\mathrm{P}_{2} \mathrm{O}_{5} @ 80 \mathrm{~kg} \mathrm{ha}^{-1}$ & 1930.50 & 1240.00 & 47.52 & 910.25 \\
\hline $\mathrm{P}_{5}-$ basal application of $\mathrm{P}_{2} \mathrm{O}_{5} @ 100 \mathrm{kgha}^{-1}$ & 2112.00 & 1370.00 & 47.92 & 998.99 \\
\hline $\mathrm{P}_{6}-$ basal application of $\mathrm{P}_{2} \mathrm{O}_{5} @ 120 \mathrm{~kg}$ & 2029.50 & 1315.00 & 46.53 & 954.05 \\
\hline S. Em. ( \pm ) & 76.97 & 56.70 & 1.16 & 42.76 \\
\hline C.D. $(p=0.05)$ & 228.70 & 168.48 & 3.44 & 127.05 \\
\hline C.V. $(\%)$ & 8.66 & 9.47 & 5.02 & 10.30 \\
\hline
\end{tabular}


Table 3: Production economic analyses (hectare $^{-1}$ basis)

\begin{tabular}{lllll}
\hline Treatments & $\begin{array}{l}\text { Cost of } \\
\text { Production (A+B) }\end{array}$ & $\begin{array}{l}\text { Gross return } \\
\text { (yield×selling price) }\end{array}$ & $\begin{array}{l}\text { Net return } \\
\text { (GR-CoP) }\end{array}$ & $\begin{array}{l}\text { Cost:Benefit } \\
\text { Ratio (NR/CoP) }\end{array}$ \\
$\mathbf{P}_{\mathbf{0}}$ - Control (No $\mathrm{P}_{2} \mathrm{O}_{5}$ ) & 37294 & 67551 & 30257 & 0.81 \\
$\mathbf{P}_{\mathbf{1}}$ - basal application of $\mathrm{P}_{2} \mathrm{O}_{5} @ 20 \mathrm{~kg} \mathrm{ha}^{-1}$ & 37494 & 69069 & 31575 & 0.84 \\
$\mathbf{P}_{2}$ - basal application of $\mathrm{P}_{2} \mathrm{O}_{5} @ 40 \mathrm{~kg} \mathrm{ha}^{-1}$ & 37694 & 77418 & 39724 & 1.05 \\
$\mathbf{P}_{3}$ - basal application of $\mathrm{P}_{2} \mathrm{O}_{5} @ 60 \mathrm{~kg} \mathrm{ha}^{-1}$ & 37894 & 78936 & 41042 & 1.08 \\
$\mathbf{P}_{4}$ - basal application of $\mathrm{P}_{2} \mathrm{O}_{5} @ 80 \mathrm{~kg} \mathrm{ha}^{-1}$ & 38094 & 88803 & 50709 & 1.33 \\
$\mathbf{P}_{5}$ - basal application of $\mathrm{P}_{2} \mathrm{O}_{5} @ 100 \mathrm{~kg} \mathrm{ha}^{-1}$ & 38294 & 97152 & 58858 & 1.53 \\
$\mathbf{P}_{6}$ - basal application of $\mathrm{P}_{2} \mathrm{O}_{5} @ 120 \mathrm{~kg}$ & 38494 & 93357 & 54863 & 1.42 \\
\hline
\end{tabular}

different levels of phosphorus application. Among the different phosphorus levels, basal application of $\mathrm{P}_{2} \mathrm{O}_{5} @ 100 \mathrm{~kg}^{-1}$ i.e. $\mathrm{P}_{5}$ registered the highest oil content of $47.92 \%$ and oil yield of $998.99 \mathrm{~kg} \mathrm{ha}^{-1}$. The results are in conformity with the findings of Bandopadhyay and Samui (1999), Ranjit et al. (2007) and Shiva Kumar et al. (2014).

\section{Economics}

The maximum cost of production ( $₹ 38494 \mathrm{ha}^{-1}$ ) was recorded by $\mathrm{P}_{6}$ (Basal application of $\mathrm{P}_{2} \mathrm{O}_{5} @ 120 \mathrm{~kg}$ ) followed by $\mathrm{P}_{5}$ (Basal application of $\mathrm{P}_{2} \mathrm{O}_{5} @ 100 \mathrm{~kg}$ $\mathrm{ha}^{-1}$ ). The lowest cost of production (₹ $37294 \mathrm{ha}^{-1}$ ) was recorded by $\mathrm{P}_{0}\left(\mathrm{No}_{2} \mathrm{P}_{5}\right)$. The highest gross return of (₹ 97152 ha-1 $^{-1}$ ) was recorded by $\mathrm{P}_{5}$ (basal application of $\mathrm{P}_{2} \mathrm{O}_{5} @ 100 \mathrm{~kg} \mathrm{ha}^{-1}$ ) and the lowest gross return ( $₹$ 67551ha-1 ${ }^{-1}$ was recorded by $\mathrm{P}_{0}$ (No $\mathrm{P}_{2} \mathrm{O}_{5}$ ). The maximum net return of ( $₹ 58858 \mathrm{ha}^{-1}$ ) was recorded by $\mathrm{P}_{5}$ (basal application of $\mathrm{P}_{2} \mathrm{O}_{5} @ 100$ $\mathrm{kg} \mathrm{ha}^{-1}$ ) and the lowest gross return (₹ $30257 \mathrm{ha}^{-1}$ ) was recorded by $\mathrm{P}_{0}\left(\mathrm{No} \mathrm{P}_{2} \mathrm{O}_{5}\right)$. In terms of benefit: cost ratio, the highest value (1.53) was recorded by treatment $\mathrm{P}_{5}$ (basal application of $\mathrm{P}_{2} \mathrm{O}_{5} @ 100 \mathrm{~kg} \mathrm{ha}^{-1}$ ) and the lowest benefit: cost ratio (0.81) was recorded by $\mathrm{P}_{0}\left(\mathrm{No}_{2} \mathrm{O}_{5}\right)$.

\section{CONCLUSION}

From the present investigation it may be concluded that groudndut may be cultivated with the basal application of $\mathrm{P}_{2} \mathrm{O}_{5} @ 100 \mathrm{~kg} \mathrm{ha}^{-1}$ during summer season in south Odisha conditions.

\section{ACKNOWLEDGEMENTS}

The authors are grateful to the authority of M.S. Swaminathan School of Agriculture, Centurion University of Technology and Management for funding and necessary support to carry out the experiment.

\section{CONCLUSION}

Thus, the following conclusion can be drawn from present investigation, Basal application of $\mathrm{P}_{2} \mathrm{O}_{5}$ beyond $100 \mathrm{~kg} \mathrm{ha}^{-1}$ significantly decreased the yield attributes and yield of groundnut.

\section{REFERENCES}

Agasimani, C.A. and Babalad, H.B. 1991. Recent advances in agronomy of groundnut (Arachis hypogaea L.). Journal of Oil seeds Research, 8: 133 - 158.

Bandopadhyay, P. and Samui, R.C. 1999. Response of kharif groundnut to varying levels of phosphorus, potassium and sulphur in West Bengal. Journal of Oilseeds Research, 16: 82-85.

Barik, A., Jana, P.K. Sounda, G. and Mukherjee, A.K. 1994. Influence of Nitrogen, phosphorus and potassium fertilization on growth, yield and oil content of kharif groundnut. Indian Agriculture, 38(2): 105 - 111.

Devi, T.C.C. and Reddy, M.G.R. 1991. Effect of gypsum, N and $P$ fertilizer on groundnut, Indian Journal of Agronomy, 36(2): 265-266.

Naphade, P.S., Naphade, K.T. and Naphade, A.H. 1991. Response of peanut to various sources of phosphatic fertilizers. Annals of Plant physiology, 5: 58-63.

Pasricha, N.S. and Aulakh, M.S. 1986. Role of sulphur in the nutrition of groundnut. Fertilizer News, 31(9): 17-21.

Pushpendra Singh., Varma, B.S. and Sahu, M.P. 1994. Effect of level and source of phosphorus and bio-regulators on groundnut (Arachis hypogaea L.). Indian Journal of Agronomy, 39(1): 66 - 70 .

Ranjit, R., Dasog, G.S. and Patil, P.L. 2007. Effect of lime and phosphorus levels on the pod, haulmand oil yield of the two groundnut genotypes in acid soils of coastal agro eco system of Karnataka. Karnataka Journal of Agriculture Science, 20(3): 627-630. 
P. Kumar et al.

Rao, S.S. and Shakawat, M.S. 2001. Effect of organic manure, phosphorus and gypsum on growth, yield and quality of groundnut (Arachis hypogaea L.). Indian Journal of Plant Physiology, 6(3): 306-311.

Sharma, B.M. and Yadav, J.S.P. 1997. Availability of phosphorus to grain as influenced by phosphatic fertilization and irrigation regimes. Indian Journal of Agriculture Science, 46: $205-210$.
Shiva Kumar, L. Radder, B. and Manasa, V. 2014. Effect of nitrogen and phosphorus levels and ratios on yield and nutrient uptake by groundnut in northern transition zone of Karnataka, The Bioscan, 9(4): 1561-1564. 